\title{
Cytotoxicity and Antifungal Properties of Hydroxychavicol Against Trichophyton rubrum
}

\author{
P. M. Ridzuan ${ }^{a^{*}}$, Nasir Mohamad ${ }^{b}$, Salwani Ismail ${ }^{c}$, Nor Iza A. Rahman ${ }^{c}$, Hairul Aini H. ${ }^{d}$, B. Zunariah ${ }^{d}$, M. H. \\ Noraziane, Baharudin Roesnita ${ }^{\dagger}$ \\ ${ }^{a}$ Management \& Science University, Department of Pre-Clinical, International Medical School, 40100 Shah \\ Alam, Selangor, Malaysia. \\ ${ }^{b}$ Universiti Sultan Zainal Abidin, School of Clinical Medicine, Faculty of Medicine, 20400 Kuala Terengganu, \\ Terengganu, Malaysia. \\ 'Universiti Sultan Zainal Abidin, School of Pre-Clinical, Faculty of Medicine, 20400 Kuala Terengganu, \\ Terengganu, Malaysia. \\ ${ }^{d}$ International Islamic University Malaysia, Department of Basic Medical Sciences, Kulliyyah of Medicine, \\ 25200 Kuantan, Pahang, Malaysia. \\ 'International Islamic University Malaysia, Department of Pharmaceutical Chemistry, Kulliyyah of \\ Pharmacy, 25200 Kuantan, Pahang, Malaysia. \\ ${ }^{f}$ Hospital Tengku Ampuan Afzan, Department of Pathology, Microbiology Unit, 25100 Kuantan, Pahang, \\ Malaysia.
}

\section{ABSTRACT}

Hydroxychavicol $(\mathrm{HC})$ is a phenolic compound of betel leaf (Piper betle). It has been reported to have antifungal properties against dermatophytes including $T$. rubrum. The aim of this study was to identify the effects of the $\mathrm{HC}$ against $T$. rubrum. Broth dilution method was used to determine the minimum inhibitory concentration (MIC) and minimum fungicidal concentration (MFC) of the HC. Microscopic study of the treated fungus was done by transmission electron microscope (TEM). Cytotoxicity study using pre-adipocyte (3T3-L1) cell line was performed by means of MTT cell proliferation assay. The MIC and MFC results of the $\mathrm{HC}$ were both $0.49 \mu \mathrm{g} / \mathrm{ml}$. Microscopic study revealed the destruction of the fungal cell wall and organelles. Cytotoxicity study showed $\mathrm{HC}$ to be non-toxic to the tested human cell line. In conclusion, HC may potentially be used as an alternative therapeutic agent against $T$. rubrum infections.

KEYWORDS: Hydroxychavicol, Trichophyton rubrum, antifungal properties, alternative therapeutic.

\section{INTRODUCTION}

The prevalence of fungi infection is increasing since past few years in parallel to the prevalence of immunocompromised patients. ${ }^{1}$ Cutaneous mycoses are the most common fungal infections and these fungi called as dermatophytes. ${ }^{2}$ Dermatophytes belongs to the group of filamentous fungi known as the ringworm fungi that commonly causes skin diseases in the world and these fungi use keratin in hair, skin and nails as their nutrient. These fungi are composed of three closely related genera namely Epidermophyton, Trichophyton and

Corresponding author:

Dr. P.M. Ridzuan

Department of Pre-Clinical,

International Medical School,

Management and Science University,

University Drive, Off Persiaran Olahraga,

Seksyen 13, 40100 Shah Alam, Selangor

No Tel : 013-4748695

Email : pm_ridzuan@msu.edu.my/ ridzuan_pauzi@yahoo.com
Microsporum which based on the formation and morphology of their conidia (structures of asexual reproduction). ${ }^{2,3}$ Besides, dermatophytes are classified into zoophilic, geophilic or anthropophilic depending on their normal habitat (animals, soil and humans, respectively). ${ }^{4}$ Among these groups, both zoophilic and anthropophilic dermatophytes are associated with skin infection while geophilic dermatophytes being more rarely involved in human disease. $^{3}$

One of the commonest organism involved is $T$. rubrum. It affects superficial skin such as onychomycosis \& tinea pedis. ${ }^{5}$ It produces conidia from hypha cells that can grow on a few numbers of media and at various $\mathrm{pH}, \mathrm{CO}_{2}$ concentration and temperature. $T$. rubrum has few, long, narrow and pencil-shaped macroconidia that is responsible for reproduction and provide a safe house for the filamentous fungal genome during the unstable conditions. ${ }^{6}$ The responsible virulence enzymes are keratinolytic proteases, metalloprotease and keratinases that involve during inflammatory reaction. ${ }^{7,8,9}$ 
Current available antifungal produce for the treatment are miconazole, fluconazole and terbinafine cream. ${ }^{10}$ Unfortunately, drug resistance to antifungal has become a serious issue among the medical practitioners and pharmaceutical workers. ${ }^{11}$ Resistance in this context can be classified into microbiological resistance as well as clinical resistance. ${ }^{12}$ In microbiological resistance, fungus is not susceptible to antifungal agent by in-vitro susceptibility testing, when the minimal inhibitory concentration (MIC) of the drug is greater than the susceptibility breakpoint of that organism. ${ }^{13}$ While clinical resistance refers to antifungals' inabilities to eradicate fungal infection despite of its effectiveness in-vitro that can be attributed to multiple factors related to the host, the antifungal agent or the pathogen. $^{12}$

Therefore, to overcome antifungal drug resistance issues, researchers are now looking for and developing alternative antifungal drugs that have diverse chemical structures and mechanisms of action. ${ }^{14}$ It would be interesting if the discovery drugs can be used as alternatives to current available antifungal. In this study we propose the effect of the hydroxychavicol (HC) as a new antifungal to treat $T$. rubrum species. Previous study by Norazian et al. showed that $P$. betel contained a high concentration of $\mathrm{HC}$ that can inhibit the Gram-positive and Gramnegative bacteria and also dermatophytes. ${ }^{15}$ However, the effects of the $\mathrm{HC}$ on $T$. rubrum species have not been studied well. Thus, the aim of this study was to identify the effects of $\mathrm{HC}$ as an antifungal agent against $T$. rubrum.

\section{MATERIALS AND METHODS}

\section{Test Organism}

T. rubrum ATCC 28188 was used in this study and it was maintained on Sabouraud's dextrose agar (SDA) at $28^{\circ} \mathrm{C}$.

\section{Inoculum preparation}

T. rubrum was subcultured on SDA at $28^{\circ} \mathrm{C}$ until sporulation. Sequentially, $5 \mathrm{ml}$ of sterilized distilled water was added to the sterile tube and with a sterile wire loop the spore and the fragments of the $T$. rubrum were dislodged into the tubes. The suspension was then vortexes for $15 \mathrm{~s}$. The turbidity of fungi suspension was adjusted to 0.5 MacFarland standards $\left(15 \times 10^{8} \mathrm{CFU} / \mathrm{ml}\right){ }^{16,17}$

\section{Preparation of $\mathrm{HC}$ and $\mathrm{MI}$}

HC from Piper spp. was purchased from Malaysia Sigma-Aldrich (Code: 18078) and MI was purchased from Sigma-Aldrich. Ten $\mathrm{mg}$ of $\mathrm{HC}$ and $\mathrm{Ml}$ in weight were diluted with $10 \mathrm{ml}$ sterile water. Two-fold serial dilution were done to make $\mathrm{HC}$ concentrations of $1000,500,250,125,62.5,31.25,15.625,7.8125$,
$3.9062,1.9531,0.9765,0.4882,0.2441,0.1220$, $0.0610,0.0305,0.0152,0.0076,0.0038 \mu \mathrm{g} / \mathrm{ml}$ for experiment procedure. ${ }^{18}$

\section{Minimum Inhibitory Concentration (MIC)}

MIC was determined by using broth microdilution assay according to NCCLS recommendation and performed in 96-well round bottom microtitre plate. ${ }^{17,19}$ Each well of microtiter plate was filled with $180 \mu \mathrm{l}$ of the adjusted inoculum. Control experiment without test compounds was carried out for verification of normal growth. Results were obtained after 7 days of incubation at $28^{\circ} \mathrm{C}$. A drop of $0.25 \%$ MTT (3-[4,5-dimethylthiazol-2-yl]-2,5diphenyl-tetrazolium bromide, SIGMA, M2128) in distilled water was added to the mixtures in each well subsequent to incubation for $30 \mathrm{~min}$. A colour change from yellow to purple indicated active metabolism, and that fungal growth had occurred. The lowest concentration at which no colour change occurred was recorded as the MIC value. All samples were measured in triplicate.

\section{Fungicidal Inhibitory Concentration (MFC)}

Clear tubes from MIC experiment that showed $80 \%$ to $100 \%$ of growth inhibition was sub-cultured onto agar plates and further incubated for 7 days at $28^{\circ} \mathrm{C}$. The lowest concentration with no visible growth was defined as the MFC. ${ }^{17}$

\section{Ultra-structural Study Using Transmission Electron Microscope (TEM)}

$\mathrm{HC}$ and $\mathrm{Ml}$ concentrations used to treat the fungus were based on the obtained MIC values. $\mathrm{HC}$ and $\mathrm{MI}$ were instilled in test tube with concentration 0.49 $\mu \mathrm{g} / \mathrm{ml}$ and $0.06 \mu \mathrm{g} / \mathrm{ml}$ (MIC value) respectively. Then $180 \mu \mathrm{l}$ of the adjusted inoculum T. rubrum suspension was put into test tubes and treated with $\mathrm{HC}$ and $\mathrm{Ml}$ for $1,3,5$ and 7 days with some modification. ${ }^{20}$ After the treatment, the fungi were fixed with $2.5 \%$ gluteraldehyde at $4^{\circ} \mathrm{C}$ for 15 min. After that, fixed fungi were washed for six times using distilled water. The samples were post -fixed with $2 \%$ osmium tetroxide at $4^{\circ} \mathrm{C}$ for $1 \mathrm{~h}$. The post-fixed samples were washed again for six times using distilled water. The post-fixed fungi then underwent a dehydration process. The samples were dehydrated in a series of graded acetone series from $70 \%$ to $90 \%$ (each for $10 \mathrm{~min}$ ) and then dehydrated with acetone $100 \%$ for $15 \mathrm{~min}$ each for three times. The dehydrated samples were infiltrated with acetone. Then, the fungi were embedded with $100 \%$ resin and were kept overnight. After that, the fungi were polymerised in an oven at $60^{\circ} \mathrm{C}$ for $24 \mathrm{~h}$. The next day, the samples were cut into ultrathin sections using ultra-microtome. The sectioned samples were then stained using Reynold staining for $10 \mathrm{~min}$ before examining them under TEM. Untreated $T$. rubrum was used as a control sample. 


\section{Cytotoxicity Study}

HC was diluted with Dulbecco's Modified Eagle Medium (DMEM) to make up stock concentration of $0.49 \mu \mathrm{g} / \mathrm{ml}$ (MIC value). Cytotoxicity test was performed to screen the $\mathrm{HC}$ toxicity effects on cell lines. It was done using 3-(4, 5-Dimethylthiazol-2yl)-2, 5-diphenyltetrazolium bromide (MTT) cell proliferation assay as described by Mosmann with some modifications. ${ }^{21}$ Cell lines pre-adipocytes (3T3-L1) were grown in complete growth medium (DMEM with $10 \%$ foetal bovine serum and $1 \%$ penicillin-streptomycin) in 96 well plate with density of $1.0-2.0 \times 10^{5}$ cells $/ \mathrm{ml}$. The well plate was incubated at $37^{\circ} \mathrm{C}$ with $5 \%$ of carbon dioxide $\left(\mathrm{CO}_{2}\right)$ to allow cells to adhere to well. After reaching confluence, the cells were treated with $\mathrm{HC}$ and $\mathrm{MI}$.

After $24 \mathrm{~h}$ of treatment, the $\mathrm{HC}$ was discarded and cell was washed with $30 \mu \mathrm{l}$ phosphate-buffered saline (PBS) at pH 7.2 for each well. Then, $20 \mu \mathrm{l}$ of MTT solution was added to each well and the plate was again incubated at $37^{\circ} \mathrm{C}$ with $5 \%$ of $\mathrm{CO}_{2}$ for 4 hours. Next, $100 \mu \mathrm{l}$ of DMSO was added to each well once the $4 \mathrm{~h}$ period ends to stop the MTT reaction and solubilize the purple formazan crystal. The plate was left at room temperature for $1 \mathrm{~h}$ prior measurement of spectrophotometric absorbance using TECAN infinite M200, multi detection microplate reader at $570 \mathrm{~nm}$ wavelength and $630 \mathrm{~nm}$ reference wavelengths. The 50\% reduction in cell number relative to the control $\left(\mathrm{IC}_{50}\right)$ was established by extrapolation from the graph of experimental data.

\section{RESULTS}

The MIC and MFC of HC were both $0.49 \mu \mathrm{g} / \mathrm{ml}$ whereas for $\mathrm{Ml}$ the values were both $0.06 \mu \mathrm{g} / \mathrm{ml}$ (Table 1).

Table 1: Antifungal activity of $\mathrm{HC}$ and $\mathrm{Ml}$ against $T$. rubrum

\begin{tabular}{cccc}
\hline \multicolumn{2}{c}{$\mathrm{HC}$} & \multicolumn{2}{c}{$\mathrm{Ml}$} \\
\hline MIC $(\mu \mathrm{g} / \mathrm{ml})$ & $\begin{array}{c}\text { MFC }(\mu \mathrm{g} / \\
\mathrm{ml})\end{array}$ & MIC $(\mu \mathrm{g} / \mathrm{ml})$ & $\begin{array}{c}\text { MFC }(\mu \mathrm{g} / \\
\mathrm{ml})\end{array}$ \\
0.49 & 0.49 & 0.06 & 0.06 \\
\hline
\end{tabular}

Figure 1 showed the hypha of the treated $T$. rubrum visualized under TEM. The untreated fungal hypha was used as a control to compare the morphological changes before and after the treatment with $\mathrm{HC}$ and MI. Untreated fungal hypha clearly showed the cell wall, cell membrane and organelles of the fungus. Figure 1 displayed the $T$. rubrum hypha treated with $0.49 \mu \mathrm{g} / \mathrm{ml}$ and 0.06 $\mu \mathrm{g} / \mathrm{ml}$ of $\mathrm{HC}$ and Ml respectively. Generally, the fungal hypha showed a morphological change once exposed to the HC and MI. Fungi treated with HC displayed severe cytoplasm destruction and thickened cell wall. Moreover, the cell membrane also started to disintegrate and desolation of the organelles occurred when exposed to $\mathrm{HC}$ at this concentration. As $\mathrm{HC}$, treatment with $\mathrm{Ml}$ also caused severe destruction to cytoplasm content as well as detachment of the cell membrane from the cell wall. Both $\mathrm{HC}$ and $\mathrm{Ml}$ cause severe damage to cell wall and organelles of the fungal hypha.

Cytotoxicity result showed that $\mathrm{HC}$ was not toxic to the tested cells. The cell viability percentage was more than $50 \%$ at all sample concentrations (Figure 2).

\section{DISCUSSION}

The MIC and MFC are considered as a standard method to determine the minimum concentration which can inhibit the organisms to antimicrobials and other testing chemicals. ${ }^{22}$ In this study, value of MIC and MFC for HC are the same. This result were performed in three replicates to ensure that the endpoint of minimum concentration was strongly confirmed visually before proceeding with spectrophotometer analysis. ${ }^{23}$ This MIC and MFC results are similar with research that has been done by Natarajan et.al, which showed that the MIC and MFC for three different extractions of 'neem' seed extract were similar against $T$. rubrum. ${ }^{24}$ Different findings were obtained by Ali et al. who found that the MIC and MFC for hydroxychavicol tested on $T$. rubrum were slightly higher than our study which was $31.25 \mu \mathrm{g} / \mathrm{ml} .{ }^{25}$ In contrary, research by Massiha \& Muradov showed different MIC and MFC values against $T$. rubrum using extraction of ten plant species traditionally used by Iranian with MIC and MFC values ranging from 0.2 to $12.5 \mathrm{mg} / \mathrm{ml}$ and 0.8 to $15.62 \mathrm{mg} / \mathrm{ml}$ respectively. ${ }^{26}$

This is consistent with the report that, low activity of antimicrobial agent has high MIC value while high activity antimicrobial agent give a low MIC value. ${ }^{27}$ Incubation time is one of the factors that influence the MIC and MFC result. However, incubation time for MIC and MFC is still a matter of debate among researches. ${ }^{22}$ Many researchers have proposed different incubation times between 3 to 20 days for dermatophytes. ${ }^{28}$ This is different from the research that was reported by Norris \& Elewski, who exhibited the optimal grow for fungi at $28^{\circ} \mathrm{C} .{ }^{29}$ In this research incubation time was 7 days with $28^{\circ} \mathrm{C}$ which is the ideal incubation time for $T$. rubrum to grow.

Ultra-morphological study of the treated $T$. rubrum was visualized under TEM (Figure 1). The untreated fungal hypha was used as a control to compare the morphological changes before and after the treatment with HC and MI. Untreated fungal hypha clearly showed the cell wall, cell membrane and organelles of the fungus. Generally, the fungal hypha showed a morphological change once exposed to the $\mathrm{HC}$ and $\mathrm{MI}$ (Figure 1). Fungi treated with $\mathrm{HC}$ displayed severe cytoplasm destruction and thickened cell wall. Moreover, the cell membrane also started to disintegrate and desolation of the 


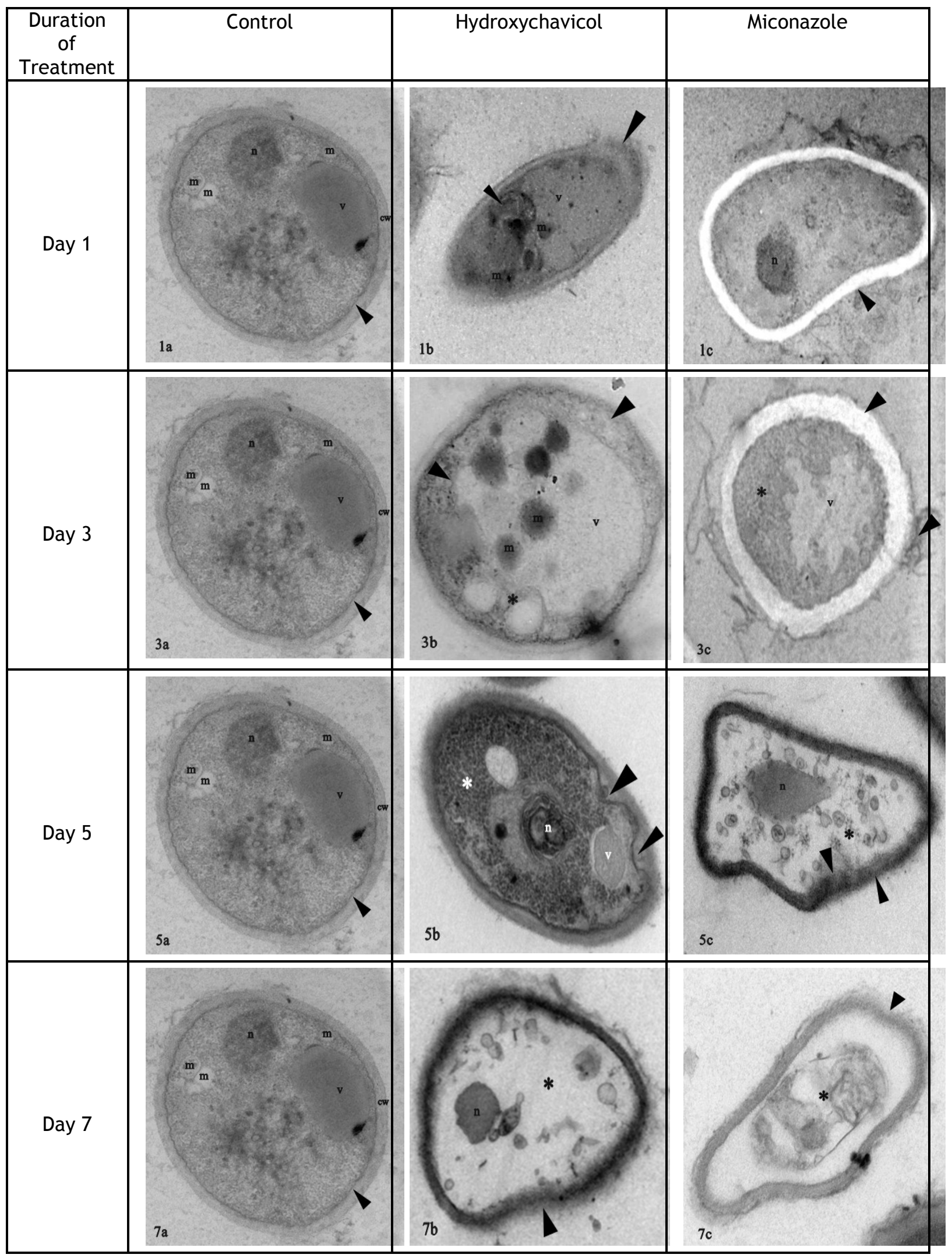

Figure 1: Transmission electron microscope (TEM) images of $T$. rubrum hypha section treated with $0.48 \mu \mathrm{g} / \mathrm{ml}$ of $\mathrm{HC}$ and $0.06 \mu \mathrm{g} / \mathrm{ml}$ of $\mathrm{Ml}$ in different duration of treatment. Untreated control samples $(1 \mathrm{a}, 3 \mathrm{a}, 5 \mathrm{a}, 7 \mathrm{a})$ showed a normal morphology with intact cell walls and cytoplasma. The images showed clear mitochondria $(m)$, vesicle $(v)$, nucleus $(n)$ and cell wall (cw). In T. rubrum treated with $\mathrm{HC}$ and $\mathrm{Ml}$ for day 1 showed thickened cell wall and organelles slowly degraded (1b). Some cells displayed severe cytoplasm destruction and thickened cell wall for three days treatment $(3 b, 3 c)$. For five days treatment, the cell membrane started to disintegrate and desolation of the organelles occurred when exposed to $\mathrm{HC}$ and $\mathrm{MI}(5 \mathrm{~b}, 5 \mathrm{c})$. Cell cytoplasm showed severe destruction and was degraded as shown by small membrane vesicles and many big vacuoles $\left({ }^{*}\right)$. Cell wall detached from the cell membrane $(7 \mathrm{~b})$ and all organelles were destructed into small vesicles (7c). Both $\mathrm{HC}$ and $\mathrm{Ml}$ cause severe damage to cell wall and organelles of the fungal hypha. 
organelles occurred when exposed to $\mathrm{HC}$ at this concentration. As $\mathrm{HC}$, treatment with $\mathrm{Ml}$ also caused severe destruction to cytoplasm content as well as detachment of the cell membrane from the cell wall. Both $\mathrm{HC}$ and $\mathrm{MI}$ cause severe damage to cell wall and organelles of the fungal hypha. This study found that $\mathrm{HC}$ was effective in inhibiting $T$. rubrum hypha by disrupting the cell wall rigidity and damaging the fungal organelles. In addition, this study showed that $\mathrm{HC}$ can be a potential antifungal because it has the ability to affect the growth of hypha at low concentration $(0.48 \mu \mathrm{g} / \mathrm{ml})$.

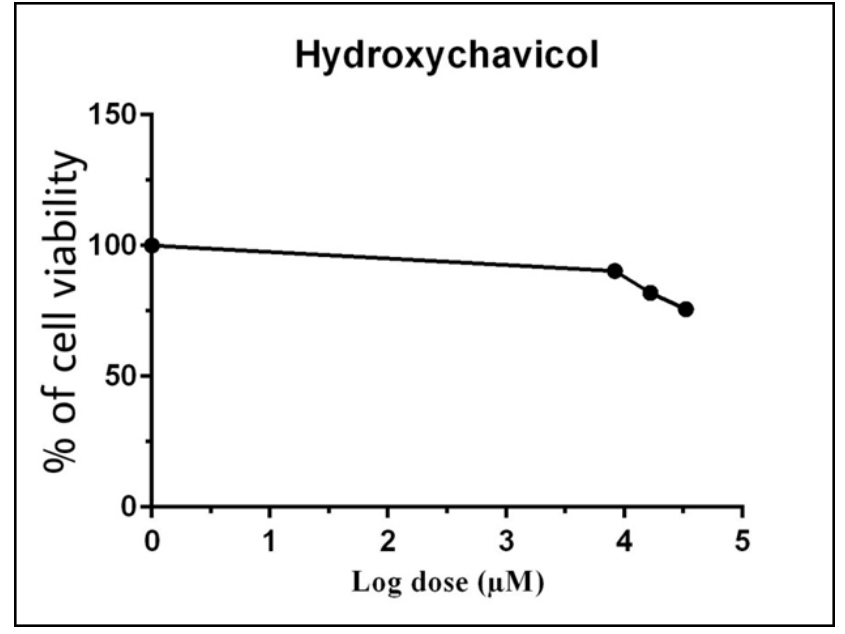

Figure 2: Result of cytotoxicity activity on 3T3-L1 treated with $\mathrm{HC}$ showed the $\mathrm{HC}$ non-toxic and percentage of the cell viability more than $50 \%$.

Furthermore, the effect of $\mathrm{Ml}$ on fungi shows a similar effect with $\mathrm{HC}$. Based on the observation from the TEM images, HC was found able to inhibit $T$. rubrum hypha by damaging the fungal cell wall, separating the cell membrane and disorganising the cytoplasmic components. The study by Farzad et al. found that garlic extract containing allicin inhibited the growth of $T$. rubrum hypha through shrinking and flattening of the cell and through cell wall demolition. ${ }^{20}$ The same action of fungal destruction might be possessed by HC. Thus, this finding gives more understanding regarding the mechanisms of action of $\mathrm{HC}$ on $T$. rubrum hypha. Another research that has been done to discover the new antifungal drug using Paenibacillus kribbensis POC 115 against the $T$. rubrum was done by Cotta et al. in 2012 . In their study, antimicrobial substance (AMS) produced by POC 115 genome caused the disruption of cytoplasmic membrane of $T$. rubrum and it appeared to be a good potential antifungal for dermatophyte especially against $T$. rubrum species. $^{30}$

Cytotoxicity result shown $\mathrm{HC}$ was not toxic to the tested cells. The cell viability percentage was more than $50 \%$ at all sample concentrations (Figure 2). In this study, MTT cell proliferation assay was conducted to screen for HC cytotoxicity activity against 3T3-LI cell lines. In vitro cytotoxicity assays with cultured cells are extensively used to test chemical sensitivity since they are rapid, economical and do not require animal use. The MTT assay is a colorimetric assay that measures viability of cells through cells ability to reduce yellow tetrazolium salts into purple formazan crystal. The yellow tetrazolium salts was reduced by the enzyme mitochondrial dehydrogenase that is only active in living cells. 23,31 Thus, the conversion of yellow tetrazolium salts to purple formazan crystal directly indicates the number of viable cells. Purple formazan crystal produced is dissolved using DMSO prior to spectrophotometric absorbance measurement. Higher intensity of purple colour produced indicates higher number of viable cells. In this study, amount of purple formazan crystal produced by cell exposed to treatment extracts was compared to the amount of crystal formazan produced by cells without any treatment exposure in order to evaluate the toxicity of samples on normal cell lines. From the results of this study, it is shown that $\mathrm{HC}$ was not toxic to cell lines used even at the highest concentration used.

\section{CONCLUSION}

This present study strongly implied that $\mathrm{HC}$ possess good antifungal activity against $T$. rubrum which cause dermatitis. Furthermore, from the study on cytotoxic activity, HC was not toxic to the cell lines. Thus, HC has potential for use in human as an antifungal agent.

\section{ACKNOWLEDGEMENTS}

The authors would like to thank Ministry of Education Malaysia for the research grant support through Fundamental Research Grant Scheme (FRGS/2/2014/ SKK04/UNISZA/02/1), International Medical School of Management \& Science University (MSU), Faculty of Medicine of University Sultan Zainal Abidin (UniSZA), Kulliyyah of Medicine and Kulliyyah of Pharmacy of International Islamic University Malaysia (IIUM), Department of Pathology of Hospital Tengku Ampuan Afzan (HTAA), Mr. Santhana Raj from Institute for Medical Research (IMR) and Hospital Sultanah Nur Zahirah (HSNZ).

\section{REFERENCES}

1. Turel O. Newer antifungal agents. Expert review of anti-infective therapy. Turkey: Bakirkoy Maternity and Children's Research Hospital. 2011; 9,325-38.

2. Maranhao FC, Paiao FG, Fachin AL, MartinezRossi NM. Membrane transporter proteins are involved in Trichophyton rubrum pathogenesis. J Med Microb 2009; 58:163-168.

3. Hayette MP, Sacheli R. Dermatophytosis, trends in epidemiology and diagnostic approach. Curr Fungal Infect Rep 2015; 9:164-79.

4. Perea S, Lopez-Ribot JL, Kirkpatrick WR, McAtee RK, Santillan RA, Patterson TF. Prevalence of molecular mechanisms of resistance to azole antifungal agents in Candida 
albicans strains displaying high-level fluconazole resistance isolated from human immunodeficiency virus-infected patients. Antimicrob Agents and Chemother 2001; 45:2676 $-84$.

5. Spicer WJ. Clinical Microbiology and Infectious Diseases. Churchill Livingstone Elsevier, United State America 2008.

6. Leng W, Liu T, Li R, Yang J, Zhang CW, Jin Q. Proteomic profile of dormant Trichopyton rubrum conidia. BMC Genomics 2008; 9:303.

7. Jousson $O$, Lechenne BO, Bontems B, Mignon $U$, Barblan J. Secreted subtilisn gene family in Trichophyton rubrum. Gene 2004; 339:79-88.

8. Zarei NA, Zahra M, Majid Z. Pityriasis versicolor in Ahvaz, Iran, Jundishapur. Journal of Microbiology 2009; 2:92-6.

9. Vermout S, Tabart J, Baldo A, Mathy A, Losson B, Mignon B. Pathogenesis of dermatophytosis. Mycopathologia 2008; 166:267-75.

10. Maertens JA. History of the development of azole derivatives. Clin Microbiol Infect 2004; 10:1-10.

11. Kumar V, Pandey N, Mohan N, Singh RP. Antibacterial \& antioxidant activity of different extract of moringa oleifera leaves-an in-vitro study. Int J Pharm Sc Rev Res 2012; 12:89-94.

12. Kanafani ZA, Perfect JR. Resistance to antifungal agents: mechanisms and clinical impact. Clin Infect Dis 2008; 46:120-8.

13. Sanglard D. Emerging Threats in AntifungalResistant Fungal Pathogens. Front Med (Lausanne) 2006; 3:11.

14. Nair R, Chanda S. Antimicrobial Activity of Terminalia catappa, Manilkara zapota and Piper betel Leaf Extract. Indian J Pharm Sc 2008; 70:390-3.

15. Mohd Hassan N, Latif A, Fairuz A, Sarbini H, Yusof M, Md Taib N. Bioautographic profile as standard reference for qualitative analysis of the efficacy of herbs as antiseptic and antioxidant. Proceeding paper presented at the Seminar on Medicinal and Aromatic Plants (MAPS) Herbal Globalisation: A new paradigm for Malaysian Herbal Industry, Kuala Lumpur 2009.

16. Espinel-Ingroff A, Kerkering TM. Spectrophotometric method of inoculum preparation for the in vitro susceptibility testing of filamentous fungi. Br J Clin Microbiol 1991; 29:393-4.

17. Barry AL, Craig WAH, Nadler LB, Reller CC, Swenson JM. Methods for determining bactericidal activity of antimicrobial agents; approved guideline. National Committee of Clinical Laboratory Standards 1999; 19:1-29.

18. Jesonbabu JN, Spandana N, Lakshmi AK. The potential activity of Hydroxychavicol against pathogenic bacteria. J Bacteriol Parasitol 2011; 2:2-5.

19. Marie BC. Manual of Antimicrobial Susceptibility Testing. American Society for Microbiology, United State America 2005.

20. Farzad A, Kalsom U, Rosimah N. Electron microscopy studies of the effects of garlic extract against Trichophyton rubrum. Sains Malaysiana 2003; 42:1585-90.

21. Mosmann T. Rapid colorimetric assay for cellular growth and survival: application to proliferation and cytotoxicity assays. J Immunol Methods 1983; 65:55-63.

22. Andrews JM. Determination of minimum inhibitory concentrations. J Antimicrob Chemother 2001; 48:5-16.

23. Santos DA, Hamdan JS. Evaluation of broth microdilution antifungal susceptibility testing conditions for Trichophyton rubrum evaluation of broth microdilution antifungal susceptibility testing conditions for Trichophyton rubrum. J Clin Microbiol 2005; 43:1917-20.

24. Natarajan V, Venugopal PV, Menon T. Effect of Azadirachta Indica (Neem) on the Growth Pattern of Dermatophytes. Indian Journal of Medical Microbiology 2003: 2:98-101.

25. Ali I, Khan FG, Suri KA, Gupta Satti BD, Dutt NKP, Khan IA. In vitro antifungal activity of hydroxychavicol isolated from Piper betle $\mathrm{L}$. Annals of Clinical Microbiology and Antimicrobials 2010; 9:7.

26. Massiha A, Muradov PZ. Comparison of antifungal activity of extracts of ten plant species and griseofulvin against human pathogenic dermatophytes. Res Med Sci 2015: 10:1-7.

27. Prescott LM, Harley A, Kelein DA. Microbiology. Mc Graw-Hill Companies Inc. New York 2002.

28. Fernández-Torres, Cabañes FJ. Collaborative evaluation of optimal antifungal susceptibility testing conditions for dermatophytes. Journal of Microbiol 2002; 40:3999-4003.

29. Norris HA, Elewski BE. Optimal growth conditions for the determination of the antifungal susceptibility of three species of dermatophytes with the use of a microdilution method. J Am Acad Dermatol 1999; 40:S9-13.

30. Cotta SR, Mota FF, Tupinamba G, Ishida K, Rozental S, Silva DOE. Antimicrobial Activity of Paenibacillus kribbensis POC 115 against the dermatophyte Trichophyton rubrum. World J Microbiol Biotechnol 2012; 28:953-62.

31. Ishiyama $M$, Tominaga $H$, Shiga $M$, Sasamoto $K$, Ohkura Y, Ueno K. A combined assay of cell viability and in vitro cytotoxicity with a highly water-soluble tetrazolium salt, neutral red and crystal violet. Biol Pharm Bull 1996; 19:1518-20. 